\title{
Contemporary Insights on Antibacterial and Pharmacological Importance of Cichorium intybus: A Compendious Review
}

\author{
Viabhav Kumar Upadhayay, ${ }^{1,2}$, Dinesh Pandey ${ }^{1}$, S. D. Samantaray ${ }^{3}$, S. P. Singh ${ }^{4}$ and Gohar Taj ${ }^{1 *}$ \\ ${ }^{1}$ Department of Molecular Biology \& Genetic Engineering, India \\ ${ }^{2}$ Department of Microbiology, College of Basic Sciences and Humanities, India
}

${ }^{3}$ Department of Computer Engineering, College of Technology, India

${ }^{4}$ Department of Veterinary Pharmacology \& Toxicology, College of Veterinary and Animal Sciences, GBPUA\&T, Pantnagar (U. S. Nagar)-263145, Uttarakhand, India

*Corresponding author: Gohar Taj, Department of Molecular Biology \& Genetic Engineering, College of Basic Sciences and Humanities, GBPUA\&T, Pantnagar (U. S. Nagar)-263145, Uttarakhand, India

\section{ARTICLE INFO \\ Received: April 09, 2021}

Published: 豐 April 19, 2021

Citation: Upadhayay VK, Gohar Taj, Pandey D, Samantaray SD, Singh SP. Contemporary Insights on Antibacterial and Pharmacological Importance of Cichorium intybus: A Compendious Review. Biomed J Sci \& Tech Res 35(2)-2021. BJSTR. MS.ID.005662.

Keywords: Cichorium Intybus; Antibacterial; Pharmacological Benefits; Phytochemicals

\begin{abstract}
The astonishing medicinal herb Cichorium intybus is well-known for its huge therapeutic potential. It is an important element of ethnic medication systems practiced in different regions of globe and also consumed as salad or vegetable. A broad spectrum of phytochemicals (chicoric acid, cinnamic acid, caftaric acid, coumarin, anthocynine, triterpenoids, chlorogenic acids, sesquiterpene lactones, caffeic acid, phenolics, flavonoids, inulin, tannin and other chemical entities) in various plant parts have been explored, identified and validated for some medicinal uses. The antibacterial traits of herbal extracts have been depicted against bacteria to diminish the rampant use of synthetic antibiotics. The hepatoprotective, anti-diabetic antioxidant, anti-inflammation, antimalarial, antiproliferative, Immunoactivity and other pharmacological benefits of extract or bioactive compounds were compiled. In this study, a plenty of features including ethnic uses, phytochemical constituents, antibacterial activity, and pharmacological application of Cichorium intybus are described concisely, that may offer an authentic source for further development and exploration of Cichorium intybus for its promising medicinal application.
\end{abstract}

\section{Introduction}

Nature provides remedial benefits for mankind through medicinal plants. The human being at somewhat suffering from various ailments and relies on different therapies which are being practiced throughout the world. Besides the modern therapies including allopathy, the ethnic people have the firm believe in herbal plants. Providing treatment through herbal plants may ascribe as 'herbal therapy', and it is a conventional mode of treatment employs in various ethnic practices (Ayurveda, Unani and Siddha) [1]. In India, several plants are being employed for curing various ailments. Even the ancient scriptures such as 'Atharvaveda' and 'Ayurveda' illustrated the remedial application of medicinal herbs [2].
Cichorium intybus ('chicory' in English and 'kasani' in Sanskrit) belong to 'Asteraceae' family, already ascribed for its noteworthy therapeutic values in 'Ayurvedic medication system' [3]. Different portions of this medicinal herb have shown excellent medicinal properties. Besides using as a traditional/ethnic medicine, the consumption of this as edible food or salad is also common. As a part folk medicine, the root, leaves, seeds, flower and even the entire plant are utilized to treat different ailments in different nations (Armenia, India, Pakistan, Turkey, South Africa, Georgia, Italy, Iran, Jordan, Morocco, Serbia) [4,5]. It has exhibited marvelous effect as hepatoprotective agent [6] and also gave the natural supplement to cure diabetes [7]. Other beneficial roles showed by chicory are 
antioxidant, anti-inflammatory, antimalarial, antiproliferative and antiulcerogenic [4]. Besides showing curative properties against number of diseases, this plant was also explored to possess admirable antibacterial activities too [8].

Currently, the extensive antibiotics use engendered the jeopardy of development of drug resistance pattern in bacteria. Therefore, the exploration of plants with therapeutic benefits has been increased as different constituents of plants are affluent with phytochemicals which inhibit bacterial progression [9]. Wide arrays of bioactive constituents (phenolic compounds, flavonoids, quinones terpenes, saponins and alkaloids) kill bacteria through adapting some cidal actions such.

a) Disruption of the cytoplasmic membrane.

b) Induction of ROS (reactive oxygen species) production.

c) Inhibitory effect against biofilm formation.

d) Hampering cell wall formation.

e) Inhibition of microbial DNA replication.

f) Reduction in energy synthesis and

g) Inactivation of cell envelope transport proteins and microbial adhesions.

h) Enzyme inactivation, and

i) Efflux pump inhibition [10-12].

All parts of chicory have shown antibacterial activities and thus expand its use to cure general infectious ailments caused by pathogenic bacteria. We herein attempted to review antibacterial activities and other medicinal properties of Cichorium intybus evaluated on studies (both 'in vitro' and 'in vivo') performed in past decades. This concise report deciphering bioactivities of the extract/bioactive compound will provide the base for the further progression and exploration of Cichorium intybus for medicinal uses.

\section{Cichorium Intybus as Ethnic Herb}

Ethnic communities have the wisdom to treat particular disease by using particular medicinal plants, so build a strong bond between human and traditional plants. The traditional knowledge regarding the exploration of herbs bearing medicinal values is transmitted from generation to generation and thus presents ancient wisdom of herbal plants to serve the local people to survive against various ailments. Chicory is also a widely accepted 'medicinal herb' and many communities know its medicinal uses. It is majorly grown in Europe, North America, Asia, some parts of Africa and Egypt, Iran and other regions of the globe [13-15]. In Asia and Europe, various preparation of chicory is helpful to cure wide level of diseases including the healing of wound and diabetes, and in Chile, it is consumed as 'winter vegetable' [16]. The leaves are consumed as 'salad' and 'vegetable' in Mediterranean food [17].

In traditional medication system (Ayurveda, Siddha and Unani), the different preparations of this pant (chicory) are given to treat ailments of the hepatic and nephritic system [18]. In India and Pakistan, this herb is potentially used in diabetes in traditional medication system and thus illustrated as well-known herbal plant to show anti-diabetic activity [19]. In countries namely Italy and Bulgaria, the decoction of chicory is popularly well-known for its hypoglycemic trait $[19,20]$. In South Africa, different plant portions including leaves, roots and stems are usually given to cure jaundice, while the 'chicory syrup' is useful for newborns [21]. In Turkey, the leaves are bringing in use to make the ointment containing wound healing trait and root decoction is given for other ailments including cancer and kidney stones [22,23]. The root portion of chicory in folklore medicine is prominently used in curing liver associated ailments and the inflammation of urinary tract $[24,25]$. Both the imperative parts of plants (leaves and roots) are useful for blood purification and also considered to have anti-arteriosclerosis, antispasmodic, anti-arthritis, laxative and hypotensive activities [26]. In Serbia, the root-decoction is mainly reported to use in liver complaints, diabetes [27], and flower infusion is effective in Diarrhea [28]. In Indian ethno-medication system, numerous plant parts of chicory are utilized in treating several diseases.

The seed has been determined to treat liver disorders [29], while root-decoction is given in some other complications (liver enlargement jaundice, gout, and rheumatism) [30]. The root decoction of chicory under herbal based remedies is also listed against diabetes in Pakistan [31]. In Morocco, the 'whole chicory plant' is traditionally important in kidney disorder and diabetes [32], while in Iranian ethnomedicine system the entire plant is employed as botanical drugs for various traditional uses (eupeptic, laxative, stomachic, depurative, choleretic, hypotension, and antipyretic) [33]. Cichorium intybus has the prevalent distribution [23] and it is also bringing in use as 'forage' or 'grazing' chicory and provides high-quality feed for live stocks with exhibiting antihelminthic trait [34]. In several countries, various plant parts of the Cichorium intybus are used in ethnoveterinary medication for healing purpose and prophylactic uses in both livestock and humans $[35,36]$. The ethnic wisdom of chicory widens the advanced research platform to further validate the remedial importance of this plant to derive the active herbal-based therapeutics agents.

\section{Phytochemical Constituents}

Secondary metabolites or other phytochemicals draw the special attention of worldwide researchers. The variety of chemicals may differ in type of plant parts, and hence huge localization of potential phytochemicals in a specific part of plant depicts its strong medicinal uses. The phytochemicals synthesis may vary depending on numerous aspects such as 
a) Different varieties or species of plant.

b) Environmental conditions.

c) Agricultural practices and

d) Post-harvest handling.

Moreover, the difference in phytochemicals can be ascribed because of the geographic differences (soil types, humidity, precipitation level, and intensity of light) $[37,38]$. The plant of Cichorium intybus is laden with numerous groups of chemical entities which introduce multiple medicinal traits. A range of phytochemicals including 'alkaloids', 'flavonoids', 'phenolic compounds', 'sesquiterpene lactones', 'chicoric acid', 'caffeic acid', 'caftaric acid', 'cinnamic acid', 'coumarin', 'anthocynine', 'chlorogenic acids', 'inulin', 'volatiles compounds', 'polysaccharides', 'tannins' etc are proficiently prevailed in chicory plant [4,39-41]. Figure 1 depicts the representative phytochemicals in four important plant parts (leaves, root, seed and flower). The leaves is prevailed with the bioactive compounds including hydroxycinnamic acids ('gallic', 'protocatechuic', 'caftaric', 'chlorogenic', 'caffeic'and 'cichoric acids'); the flavonoids ('luteolin 7-0-glucuronide', 'apigenin', 'apigenin glucuronide','apigenin 7-0-arabinoside','quercetin3-0-glucuronide', 'quercetin 3-0-galactoside', 'quercetin 3-0-rhamnoside', 'quercetin malonyl glucoside', 'kaempferol 3-0-glucoside', 'kaempferol 3-0-glucuronide', 'methyl quercetin glucuronide', 'kaempferol malonyl glucoside', 'methyl quercetin glucoside', 'isorhamnetin 3-0-glucuronide' and 'isorhamnetin 7-0-glucuronide'); the anthocyanins ('cyanidin 3-0-glucoside', 'cyanidin 3-0-rutinooside,' 'pelargonidin 3-0-glucoside', 'peonidin 3-0-glucoside', 'malvidin 3-0-glucoside', 'cyanidin 3-malonylglucoside', 'delphinidin 3-0(6" malonyl)-glucoside', 'cyanidin 3-0-(6" malonyl)-glucoside'), and Tannins [40-46]. The important phytochemicals including Hydroxycinnamate ('caftaric acid', 'chlorogenic acid', 'cichoric acid', '3,5-dicaffeoylquinic acid', '4,5-dicaffeoylquinic acid', and 'caffeic acid' derivatives), Sesquiterpene lactone ('11ß,13dihydrolactucin'; 'lactucin'; '8-deoxylactucin glucoside'; 'jacquinelin glucoside'; '8-deoxylactucin'; 'jacquinelin'; 'lactucopicrin/11ß,13dihydrolactucopicrin'), polysaccharide, fructose, tannin, volatile oils, inulin, sucrose, cellulose, benzoic acid, verapamil and verbenone in root [16,47-51]. Moreover, the chicory seeds harbor several phytocompounds ('sesquiterpene glycoside', 'caffeoylquinic acids', 'anthraquinone', 'syringic acid', 'beta-sitosterol', 'lupeol', 'betulinic acid', 'sigmasterol,' 'betunaldehyde', 'alkaloids', 'flavonoids', 'tannins', 'saponins' and 'vanillic acid') [4,8,52-54]. Furthermore, the flower also ascertained to contain bioactive compounds namely 'flavonoids', 'essential oils', 'anthocyanins', 'methoxycoumarin', 'cichorine', 'lactucin', 'intybin' and 'saccharides' [4,54-56].

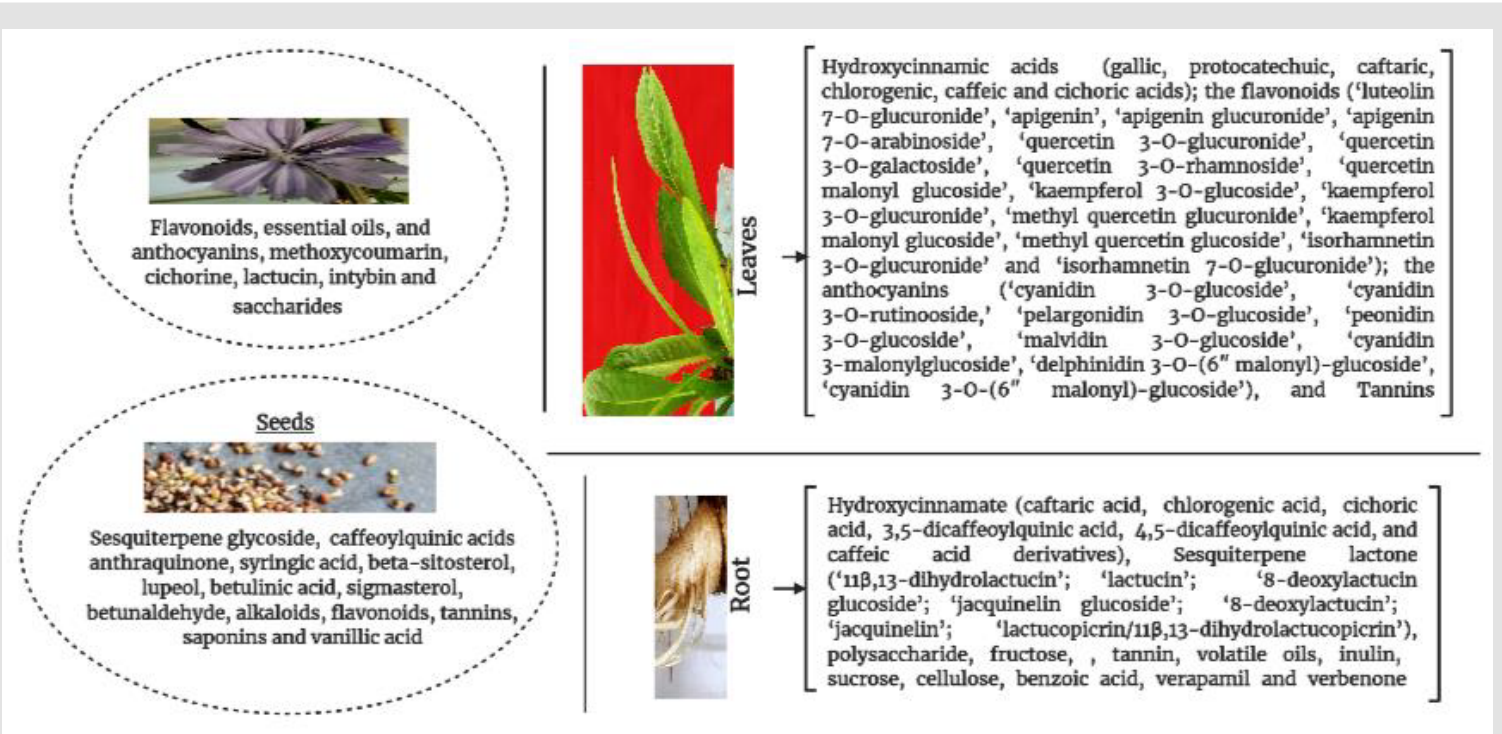

Figure 1: Diagram representing phytochemicals in different parts (leaves, shoot, seeds and flowers) of Cichorium Intybus.

\section{Need of Cichorium intybus for 'Phytotherapy'}

A huge section of world population (about $80 \%$ human populations) lives in developing nations and relies basically on herbal plants for curing health related issues [57]. Then, it needs to develop herbal formulations to treat people suffering from several ailments, and further promotion of herbal-based medicines which stated to be potential usage in the conventional medication system and validated on scientific ground. The herbal preparations used for medication are comprised of specific plant part either in 'crude' and/or 'processed' state and combination of plants containing active ingredients. Drugs from herbal/natural sources are more striking than the drug prepared from synthetic means due to many reasons such as affordability, diversity, accessibility with lesser effects [58]. A huge diversity of bioactive components exists in variety of phytochemicals also draws the therapeutic significance of chicory $[59,60]$. The content of phytochemicals may differ in whole plant/precise section of the herb and in the 
extracted material. Therefore, it becomes necessary to assess the pharmacological importance of herbal plant extract and their constituents containing phytochemicals with traits of multiple medicinal properties. Currently, a curiosity among the researchers is to widen the area of 'chicory derived herbal drugs' through understanding the mechanism of action behind showing any specific medicinal trait rather than simply relies on faith and folk or tradition. Moreover, proper studies are also to be done to illustrate the means of microbicidal efficacy of chicory in broadways that is still lack in previous studies. From the research studies, it is envisaged that government-funded laboratories; drug companies and other associated and relevant scientific communities will have a look at this medicinal herb with a view to further exploration and subsequent development of herbal products to better the lives of disease victims and to reverse the drug resistance effects of antibiotic-resistant bacteria.

\section{Cichorium Intybus: as a Natural 'Antibacterial Agent'}

Evaluating the antibacterial efficacy of plants is a fine idea over the antibiotic uses. It may decline the uncontrollable antibiotics use and associated risk factors such as the expansion of drug resistant or multidrug resistant bacteria [61]. Extracts encompasses plenty of bioactive compounds including alkaloids, phenolic compounds, coumarins, terpenes, flavonoid, saponins and organosulfur compounds, and inhibit microbial growth through different mechanisms $[62,63]$. Still the usage of herbal based materials is common in numerous ethnic groups for curing bacterial infections [64] and several herbal based compounds showed anti-microbial potential against drug-resistant bacteria and disrupted the virulence factors of pathogenic microorganisms through exhibiting 'antibiofilm activity' [65]. Chicory herbal extracts (aqueous and alcoholic extracts) have shown auspicious antibacterial traits against both kinds of bacteria.
a) Gram positive bacterial strains and
b) Gram-negative bacterial strains [66].

The leaf extracts were also evaluated against Helicobacter pylori [67] and Salmonella typhi (a multidrug resistant strain of Salmonellatyphi) [2]. The virulence-associated activities of some oral microbial pathogens (Actinomyces naeslundii, Streptococcus mutans, and Prevotella intermedia) were aborted in the response to 'low molecular mass extract' of Cichorium intybus var. silvestre ('red chicory') [68]. The tested herbal extract of Cichorium intybus presented more and promising antibacterial action but lesser antifungal activity. The silver nanoparticles prepared through green mode by using the chicory extract exhibited antibacterial property against Escherichia coli, Pseudomonas aeruginosa and Staphylococcus aureus [69]. The phytochemicals with the antibiotics act synergistically to neutralize drug resistant bacteria through exhibiting various antimicrobial mechanisms such as quelling the activity of 'antibiotic degrading enzyme', preventing target modification and blocking 'efflux pumps' [70]. Synergistic action of herbal extracts of chicory and antibiotics (amoxicillin and chloramphenicol) were examined against certain bacteria (Escherichia coli, Bacillus subtilis, Klebsiella pneumonia, Proteus mirabilis, Pseudomonas aeruginosa, Enterobacter cloacae, and Staphylococcus aureus). The resultant combinations of extracts (ethyl acetate extract and acetone extract) of chicory with the antibiotics showed 'additive' and 'indifferent' effects against some test bacterial strains [71]. An overview of herbal extracts of different portions of chicory may endow with multiple strategies for testing antibacterial activity (Figure 2). In previous studies, different parts rendered the antibacterial properties of Cichorium intybus against bacteria are given in Table1 [71-83].

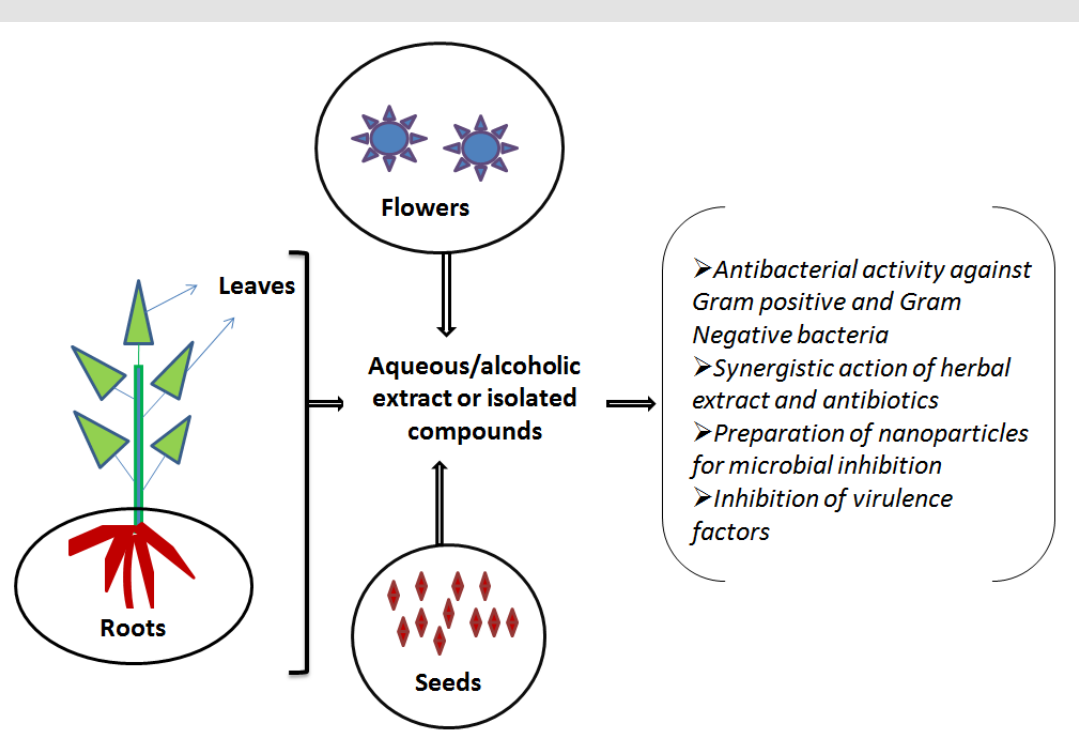

Figure 2: Multiple ways to explore antibacterial potential of Cichorium Intybus. 
Table 1: Antibacterial Activity of Cichorium Intybus Against Bacteria.

\begin{tabular}{|c|c|}
\hline Plants Parts & Tested Bacteria \\
\hline Aerial part & Staphylococcus aureus, Escherichia coli [72], Staphylococcus epidermidis [73,74] \\
\hline Root & $\begin{array}{c}\text { Bacillus subtilis [37,74-77], Escherichia coli [39,66,74-77], Erwiniacarotovora, Pseudomonas fluorescens, Sarcina lutea } \\
\text { [74], K. pneumonia [77] Micrococcus luteus [39], Pseudomonas fluorescens [74,75], Salmonella typhi [78], Staphylococcus } \\
\text { aureus [39,74,75,78], Vibrio cholera [75] }\end{array}$ \\
\hline Seeds & $\begin{array}{l}\text { Acinetobacter baumannii [79], Bacillus subtilis, Escherichia coli [54], Proteus vulgaris [80], Pseudomonas aeruginosa } \\
{[8,79], \text { Staphylococcus aureus }[8,54,79,80]}\end{array}$ \\
\hline Leaf & $\begin{array}{c}\text { Bacillus subtilis [77,81], Escherichia coli [66], Helicobacter pylori [67], K. pneumonia [77,82], Proteus vulgaris [82], } \\
\text { Pseudomonas aeruginosa [66,81,82], Salmonella typhi [2], Staphylococcus aureus }[77,81,82]\end{array}$ \\
\hline Flower & Bacillus subtilis $[83,84]$, Escherichia coli $[83,84]$, Klebsiella pneumonia [83], Staphylococcus aureus $[83,84]$ \\
\hline
\end{tabular}

\section{Medicinal Values of Cichorium Intybus}

Wide arrays of research explored the therapeutic potential of various plant parts of chicory including root, leaves, seeds, flower and even the whole plants, and also elucidated the medicinal values of isolated compounds. The Cichorium intybus is a stupendous hub of various bioactive compounds which depict medicinal values. Several medicinal importance of chicory is illustrated in Figure 3. Moreover, several pharmacological studies are based on testing the botanical extract (aqueous/alcoholic extracts) from root, leaves, and other parts including seeds of the plant.

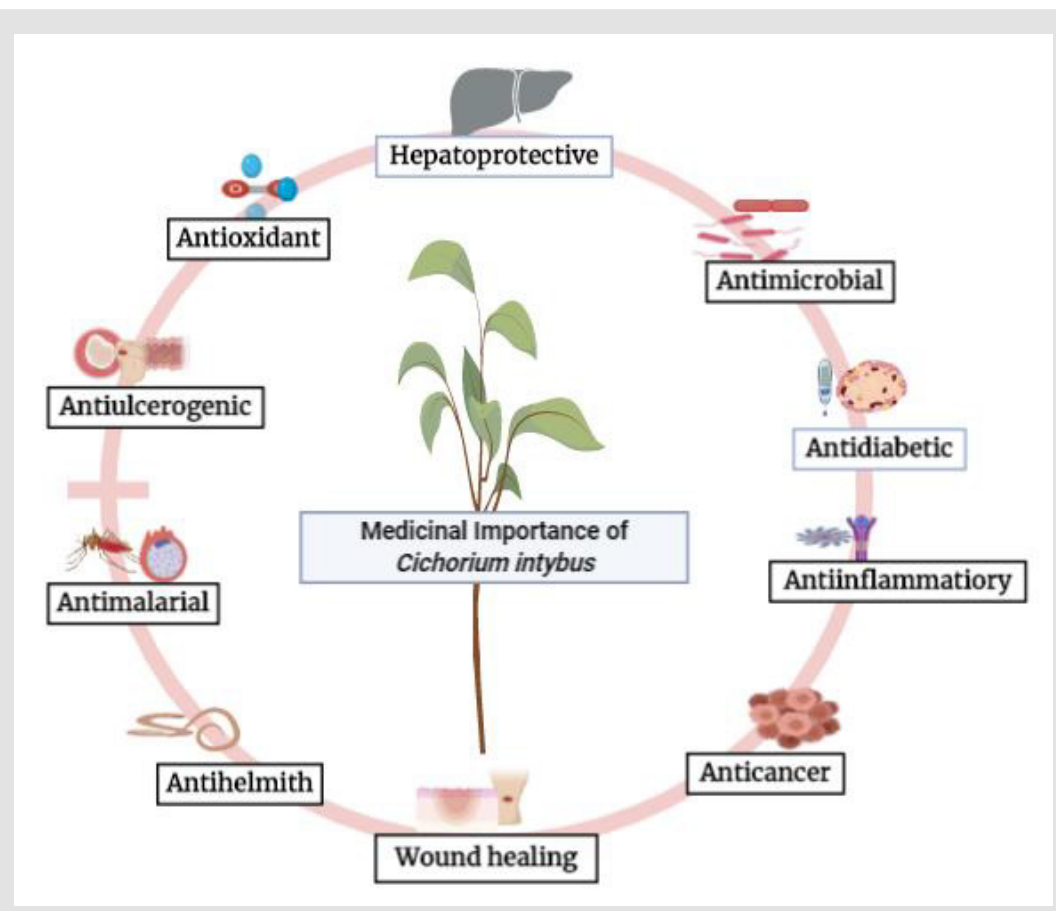

Figure 3: Important medicinal values of Cichorium Intybus.

As a herbal/natural supplement, it has shown the wide spectrum therapeutic traits such as hepatoprotective [84-87], antidiabetic [30], antibacterial [68] anti-inflammatory [88], and antioxidant [89]. As a hepatoprotective agent, it also decreases the threat of liver cirrhosis [6]. Other pharmacological application of chicory includes antihypoglycemic, antihyperlipidemic [90,91], anticancer [92], anti-allergic [93], anti-ulcerogenic [94], gastroprotective [95], anti-protozoal [96], and wound healing activities [23]. It has evaluated to be an anti-hyperuricemia agent [97], and also depicted anti-rheumatic effects [98]. Pharmaceutical significance of the herbal plant relies on the existence of lead molecule/phytochemical in different constituents of plants. Determining the bioactivities of potential phytochemical with in vivo animal studies is necessary for further exploring multitude medicinal properties of plants [40].

Recently, the development of efficient pancreatic $\beta$ cells from stem cells under proper conditions or replacing the 'degenerative pancreatic $\beta$ cells' by 'insulin-producing cells (IPCs)' depict the very auspicious option to cure diabetes $[99,100]$. Chicory extract was effectual to provoke the differentiation of 'P19 EC cells' into the clusters analogous to pancreatic islets also with exerting the functional, molecular, and cellular characteristics of 'mature $\beta$ cells' [101]. An important material substance in chicory namely 'inulin', is attributed to be beneficial for the patients with 'type 2 diabetes' [102]. A study showed potential role of root extract in 
osteoarthritis management [103]. Hydroalcoholic extracts were also helpful to defend against acute pancreatitis [104]. Important pharmacological benefits of chicory extract or isolated compound based on in vitro/in vivo studies are depicted in Table 2.

Table 2: Pharmaceutical Benefits of Extracts/Compounds from Cichorium Intybus.

\begin{tabular}{|c|c|}
\hline $\begin{array}{c}\text { Extract/Compound from Plant } \\
\text { Part }\end{array}$ & Pharmacological Benefits \\
\hline \multicolumn{2}{|c|}{ Root } \\
\hline Aqueous decoction & Anti-ulcerogenesis [95] \\
\hline Ethyl acetate extract & Antifungal [75] \\
\hline Ethanolic extract & Tumor-inhibitory [105] \\
\hline Methanolic extract & Wound healing [23] \\
\hline Aqueous extracts & Antihepatotoxic [87] \\
\hline Aqueous extract & Anti-malarial [106] \\
\hline Natural chicoric acid extract & Anti-hyperglycemic [107] \\
\hline 'Magnolialide'(from root) & Tumor-inhibitory [108] \\
\hline Aqueous-alcoholic extract & Immunoactivity [109] \\
\hline Extract (rich in chicoric acid) & Antidiabetic [19] \\
\hline Chicory root pulp & Anthelmintic [60] \\
\hline $\begin{array}{l}\text { Extracts rich in sesquiterpene } \\
\text { lactones }\end{array}$ & Anti-inflammatory [88] \\
\hline Alcoholic and aqueous extracts & Hepatoprotective [86] \\
\hline Ethanolic and aqueous extracts & Anti-inflammatory [3] \\
\hline Hydroalcoholic extract & $\begin{array}{l}\text { Beneficial effects on pyridoxine-in- } \\
\text { duced peripheral neuropathy [110] }\end{array}$ \\
\hline \multicolumn{2}{|c|}{ Leaf } \\
\hline Ethanolic extract fraction & Antioxidant activity [111] \\
\hline Tannins & Anti-diabetic [40] \\
\hline Aqueous extracts & Cardioprotective [112] \\
\hline Cichoric acid & Anti-hepatitis B [113] \\
\hline Ethanol extract & Anti-inflammatory [114] \\
\hline Aqueous extract & Bone protection [115] \\
\hline Aqueous-alcoholic macerate & Anti-proliferative [116] \\
\hline Hydroalcholic extract & Hepatoprotective [117] \\
\hline Aqueous \& ethanolic extract & Anti-ulcer [94] \\
\hline Crude hydrophilic extracts & Antioxidant [89] \\
\hline \multicolumn{2}{|c|}{ Seed } \\
\hline Aqueous-methanolic extract & Hepatoprotective [118] \\
\hline Caffeoylquinic acid-rich extract & $\begin{array}{l}\text { Improved diet-induced metabolic } \\
\text { disturbances [53] }\end{array}$ \\
\hline Aqueous extract & Repair the kidney damage [119] \\
\hline Alcoholic extract & Antihepatotoxic [29] \\
\hline $\begin{array}{l}\text { Methanolic extracts \& ethyl ace- } \\
\text { tate fraction }\end{array}$ & Antioxidant [54] \\
\hline
\end{tabular}

\section{Conclusion}

The plant of chicory (Cichorium intybus) is being practiced in ethnic system since ancient times as a natural/herbal medicinal source, and as well as a vegetable crop. Each important portion of this plant (leaves, root, seeds and flower) represent the 'medicinal phytochemistry' as a result of the presence of vast arrays of phytochemicals. Herbal extracts/bioactive components from this plant depicted the various clinical applications which had been supported by investigating some biological activities including antibacterial activities and other numerous pharmacological advantages.

\section{Acknowledgment}

We are thankful to the authorities of respective departments (a) Department of Molecular Biology \& Genetic Engineering, College of Basic Sciences and Humanities, Govind Ballabh Pant University of Agriculture \& Technology, Pantnagar (India), and (b) DBT (Department of Biotechnology)- New Delhi, for the support of carrying out this work.

\section{References}

1. Sen S, Chakraborty R (2017) Revival, modernization and integration of Indian traditional herbal medicine in clinical practice: Importance, challenges and future. J Tradit Complement Med 7(2): 234-244.

2. Rani P, Khullar N (2004) Antimicrobial evaluation of some medicinal plants for their anti-enteric potential against multi-drug resistant Salmonella typhi. Phytother Res 18(8): 670-673.

3. Rizvi W, Fayazuddin M, Shariq S, Ompal Singh, Shagufta Moin, et al. (2014) Anti-inflammatory activity of roots of Cichorium intybus due to its inhibitory effect on various cytokines and antioxidant activity. Anc Sci Life 34(1): 44-49.

4. Street RA, Sidana J, Prinsloo G (2013) Cichorium intybus: Traditional Uses, Phytochemistry, Pharmacology, and Toxicology. Evid Based Complement Alternat Med 2013: 579319.

5. Aisa HA, Xin X-L, Tang D. (2020) Chemical constituents and their pharmacological activities of plants from Cichorium genus. Chin Herb Med 12(3): 224-236.

6. Keshk WA, Soliman NA, Ali DA, Elseady WS (2019) Mechanistic evaluation of AMPK/SIRT1/FXR signaling axis, inflammation, and redox status in thioacetamide-induced liver cirrhosis: The role of Cichorium intybus linn (chicory)-supplemented diet. J Food Biochem 43(8): e12938.

7. Ghamarian A, Abdollahi M, Su X, Amiri A, Ahadi A, et al. (2012) Effect of chicory seed extract on glucose tolerance test (GTT) and metabolic profile in early and late-stage diabetic rats. DARU Journal of Pharmaceutical Sciences 20(1).

8. Shaikh T, Rub RA, Sasikumar S (2016) Antimicrobial screening of Cichorium intybus seed extracts. Arab J Chem 9: S1569-S1573.

9. Cowan MM (1991) Plant products as antimicrobial agents. Clin Microbiol Rev 12(4): 564-582.

10. Gupta P, Birdi T (2017) Development of botanicals to combat antibiotic resistance. J Ayurveda Integr Med 8(4): 266-275.

11. Mickymaray S (2019) Efficacy and mechanism of traditional medicinal plants and bioactive compounds against clinically important pathogens. Antibiotics (Basel) 8(4): 257.

12. Prasch S, Bucar F (2015) Plant derived inhibitors of bacterial efflux pumps: an update. Phytochem Rev 14(6): 961-974.

13. Montefusco A, Semitaio G, Marrese PP, Andrea Iurlaro, Monica De Caroli, et al. (2015) Antioxidants in varieties of chicory (Cichorium intybusL.) and wild poppy (Papaver rhoeasL.) of southern Italy. J Chem: 1-8.

14.Amer AM (2018) Antimicrobial Effects of Egyptian Local Chicory, 
Cichoriumendivia subsp. pumilum. Int J Microbiol: 6475072.

15. Haghighizadeh M, Zare K, Aghaie H, Monajjemi M (2020) Preparation and characterization of Chicory leaf powder and its application as a nano-native plant sorbent for removal of Acid Blue 25 from aqueous media: isotherm, kinetic and thermodynamic study of the adsorption phenomenon. Journal of Nanostructure in Chemistry 10(1): 75-86.

16. Akbar S (2020) Handbook of 200 Medicinal Plants: A Comprehensive Review of Their Traditional Medical Uses and Scientific Justifications. Cham: Springer International Publishing.

17. Lin Z, Zhang B, Li L, Wang H, Zhu C (2015) Experimental study on protective and anti-obesity effects of inulin from chicory (Cichorium intybus L.) on quail model. Integr Med Res 4(1): 2.

18. Chandra K, Jain SK (2016) Therapeutic potential of Cichorium intybus in lifestyle disorders: A review. Asian J Pharm Clin Res 9(3): 20-25.

19. Ferrare K, Bidel LPR, Awwad A, Patrick Poucheret, Guillaume Cazals, et al. (2018) Increase in insulin sensitivity by the association of chicoric acid and chlorogenic acid contained in a natural chicoric acid extract (NCRAE) of chicory (Cichorium intybus L.) for an antidiabetic effect. J Ethnopharmacol 215: 241-248.

20. Leporatti ML, Ivancheva S (2003) Preliminary comparative analysis of medicinal plants used in the traditional medicine of Bulgaria and Italy. J Ethnopharmacol 87(2-3): 123-142.

21. Van Wyk BE, OudtshoornBV, Gericke N (1997) Medicinal plants of South Africa. Briza Publications, Pretoria.

22. Sezik E, Yeşilada E, Honda G, Takaishi Y, Takeda Y, et al. (2001) Traditional medicine in Turkey X. Folk medicine in Central Anatolia. J Ethnopharmacol 75(2-3): 95-115.

23. Süntar I, KüpeliAkkol E, Keles H, Yesilada E, Sarker SD, et al. (2012) Comparative evaluation of traditional prescriptions from Cichorium intybus L. for wound healing: stepwise isolation of an active component by in vivo bioassay and its mode of activity. J Ethnopharmacol 143(1): 299-309.

24. López-Muñoz F, Alamo C, García-García P (2006) The herbs that have the property of healing: the phytotherapy in Don Quixote. J Ethnopharmacol 106(3): 429-441.

25. Schmidt BM, Ilic N, Poulev A, Raskin I (2007) Toxicological evaluation of a chicory root extract. Food ChemToxicol 45(7): 1131-1139.

26. Stanciu G, Rotariu R, Popescu A, Tomescu A (2019) Phenolic and mineral composition of wild chicory grown in Romania. Rev chimn 70(4): 11731177.

27. Jarić S, Popović Z, Mačukanović-Jocić M, Lola Djurdjević, Miroslava Mijatović, et al. (2007) An ethnobotanical study on the usage of wild medicinal herbs from Kopaonik Mountain (Central Serbia). J Ethnopharmacol 111(1): 160-175.

28. Savikin K, Zdunić G, Menković N, Jelena Zivković, Nada Cujić, et al. (2013) Ethnobotanical study on traditional use of medicinal plants in SouthWestern Serbia, Zlatibor district. J Ethnopharmacol 146(3): 803-810.

29. Ahmed B, Al-Howiriny TA, Siddiqui AB (2003) Antihepatotoxic activity of seeds of Cichorium intybus. J Ethnopharmacol 87(2-3): 237-240.

30. Pushparaj PN, Low HK, Manikandan J, Tan BKH, Tan CH (2007) Antidiabetic effects of Cichorium intybus in streptozotocin-induced diabetic rats. J Ethnopharmacol 111(2): 430-434.

31. Ahmad M, Qureshi R, Arshad M, Khan MA, Zafar M (2009) Traditional herbal remedies used for the treatment of diabetes from district attock (Pakistan). Pak J Bot 41(6): 2777-2782.

32. El-Hilaly J, Hmammouchi M, Lyoussi B (2003) Ethnobotanical studies and economic evaluation of medicinal plants in Taounate province (Northern Morocco). J Ethnopharmacol 86(2-3): 149-158.

33. Miraldi E, Ferri S, Mostaghimi V (2001) Botanical drugs and preparations in the traditional medicine of West Azerbaijan (Iran). J Ethnopharmacol
75(2-3): 77-87.

34. Heckendorn F, Häring D, Maurer V, Senn M, Hertzberg H (2007) Individual administration of three tanniferous forage plants to lambs artificially infected with Haemonchuscontortus and Cooperiacurticei. Vet Parasitol 146(1-2): 123-134.

35. Van der Merwe D, Swan GE, Botha CJ (2001) Use of ethnoveterinary medicinal plants in cattle by Setswana-speaking people in the Madikwe area of the North West Province of South Africa. J S Afr Vet Assoc 72(4): 189-196.

36. Nwafor IC, Shale K, Achilonu MC (2017) Chemical Composition and Nutritive Benefits of Chicory (Cichorium intybus) as an Ideal Complementary and/or Alternative Livestock Feed Supplement. Scientific World Journal 2017: 7343928.

37. Ghasemzadeh A, Jaafar H, Bukhori M, Rahmat M, Rahmat A (2018) Assessment and comparison of phytochemical constituents and biological activities of bitter bean (Parkiaspeciosa Hassk.) collected from different locations in Malaysia. Chem Cent J 12(1).

38. Tiwari BK, Brunton NP, Brennan CS (2013) Handbook of Plant Food Phytochemicals Sources, Stability and Extraction. Hoboken, WileyBlackwell, New Jersey.

39. Nandagopal S, RanjithaKumari B (2007) Phytochemical and Antibacterial Studies of Chicory (Cichorium intybusL.) - A Multipurpose Medicinal Plant. AdvanBiol Res 1(1-2): 17-21.

40. Muthusamy V, Anand S, Sangeetha K, Sujatha S, Arun B, et al. (2008) Tannins present in Cichorium intybus enhance glucose uptake and inhibit adipogenesis in 3T3-L1 adipocytes through PTP1B inhibition. ChemBiol Interact 174(1): 69-78.

41. Papetti A, Maietta M, Corana F, Marrubini G, Gazzani G (2017) Polyphenolic profile of green/red spotted Italian Cichorium intybus salads by RP-HPLC-PDA-ESI-MS n. J Food Compost Anal 63: 189-197.

42. Ferioli F, D’Antuono L (2012) An update procedure for an effective and simultaneous extraction of sesquiterpene lactones and phenolics from chicory. Food Chem 135(1): 243-250.

43. Heimler D, Isolani L, Vignolini P, Romani A (2009) Polyphenol content and antiradical activity of Cichorium intybus L. from biodynamic and conventional farming. Food Chem 114(3): 765-770.

44. Innocenti M, Gallori S, Giaccherini C, Ieri F, Vincieri FF, et al. (2005) Evaluation of the phenolic content in the aerial parts of different varieties of Cichorium intybus L. J Agric Food Chem 53(16): 6497-6502.

45. Sinkovič L, Demšar L, Žnidarčič D, Vidrih R, Hribar J, et al. (2015) Phenolic profiles in leaves of chicory cultivars (Cichorium intybus L.) as influenced by organic and mineral fertilizers. Food Chem 166: 507-513.

46.Zeb A, Haq A, Murkovic M (2019) Effects of microwave cooking on carotenoids, phenolic compounds and antioxidant activity of Cichorium intybus L. (chicory) leaves. Eur Food Res Technol 245(2): 365-374.

47. Fan H, Chen J, Lv H, Xiancan Ao, Yuexian Wu, et al. (2016) Isolation and identification of terpenoids from chicory roots and their inhibitory activities against yeast $\alpha$-glucosidase. European Food Research and Technology 243(6): 1009-1017.

48. Gholami H, Raouf Fard F, Saharkhiz M, Ghani A (2018) Yield and physicochemical properties of inulin obtained from Iranian chicory roots under vermicompost and humic acid treatments. Ind Crops Prod 123: $610-616$

49. Gray D, Roberts C, Rottinghaus G, Garrett H, Pallardy S (2001) Quantification of root chicoric acid in purple coneflower by near infrared reflectance spectroscopy. Crop Sci 41(4): 1159-1161.

50. Kim M, Shin HK (1996) The water-soluble extract of chicory reduces glucose uptake from the perfused jejunum in rats. J Nutr 126(9): 22362242.

51. Malarz J, Stojakowska A, Kisiel W (2013) Long-term cultured hairy roots of chicory-a rich source of hydroxycinnamates and 8-deoxylactucin 
glucoside. Appl Biochem Biotechnol 171(7): 1589-1601.

52. Atta-ur-Rahman, Zareen S, Choudhary MI, Akhtar MN, Khan SN (2008) alpha-Glucosidase inhibitory activity of triterpenoids from Cichorium intybus. J Nat Prod 71(5): 910-913.

53. Jurgoński A, Juśkiewicz J, Zduńczyk Z, Król B (2012) Caffeoylquinic acidrich extract from chicory seeds improves glycemia, atherogenic index, and antioxidant status in rats. Nutrition 28(3): 300-306.

54. Mehmood N, Zubair M, Rizwan K, Rasool N, Shahid M, et al. (2012) Antioxidant, antimicrobial and phytochemical analysis of Cichorium intybus seeds extract and various organic fractions. Iran J Pharm Res 11(4): 1145-1151.

55. Katiyar P, Kumar A, Mishra AK, Dixit RK, Kumar A, et al. (2015) Kasni (Cichorium intybus L.) A propitious traditional medicinal herb.Int ] Pharm Sci Res 2(8): 368-380.

56. Nørbaek R, Nielsen K, Kondo T (2002) Anthocyanins from flowers of Cichorium intybus. Phytochemistry 60(4): 357-359.

57. Ekor M (2013) The growing use of herbal medicines: issues relating to adverse reactions and challenges in monitoring safety. Front Pharmacol 4 .

58. Sabiu S, Madende M, Ayokun-nun Ajao A, Adepemi Ogundeji O, Lekena N, et al. (2019) The scope of phytotherapy in southern African antidiabetic healthcare. Trans R Soc S Afr 74(1): 1-18.

59. Das S, Vasudeva N, Sharma S (2016) Cichorium intybus: A concise report on its ethnomedicinal, botanical, and phytopharmacological aspects. Drug Dev Ther 7(1): 1 .

60. Peña-Espinoza M, Valente AH, Bornancin L, Henrik T Simonsen, Stig M Thamsborg, et al. (2020) Anthelmintic and metabolomic analyses of chicory (Cichorium intybus) identify an industrial by-product with potent in vitro antinematodal activity. Vet Parasitol 280(109088): 109088.

61. Cheesman MJ, Ilanko A, Blonk B, Cock IE (2017) Developing New Antimicrobial Therapies: Are Synergistic Combinations of Plant Extracts/Compounds with Conventional Antibiotics the Solution? Pharmacogn Rev 11(22): 57-72.

62. Silva NCC, Fernandes Júnior A (2010) Biological properties of medicinal plants: a review of their antimicrobial activity. J Venom Anim Toxins Incl Trop Dis 16(3): 402-413.

63. Khameneh B, Iranshahy M, Soheili V, FazlyBazzaz BS (2019) Review on plant antimicrobials: a mechanistic viewpoint. Antimicrob Resist Infect Control 8(1): 118.

64. Romha G, Admasu B, HiwotGebrekidan T, Aleme H, Gebru G (2018) Antibacterial activities of five medicinal plants in Ethiopia against some human and animal pathogens. Evid Based Complement Alternat Med: 2950758.

65. Lu L, Hu W, Tian Z, et al. (2019) Developing natural products as potential anti-biofilm agents. Chin Med 14(1): 11.

66. Verma R, Rawat A, Ganie S, Agnihotri RK, Sharma R, et al. (2013) In vitro Antibacterial activity of Cichorium intybus against some pathogenic bacteria. Br J Pharm Res 3(4): 767-775.

67. Rifat-uz-Zaman, Akhtar MS, Khan MS (2006) In vitro antibacterial screening of Anethumgraveolens L. Fruit, Cichorium intybus L. Leaf, Plantago ovata L. Seed Husk and Polygonum viviparum L. Root extracts against Helibacter pylori. Int J Pharmacol 2(6): 674-677.

68. Papetti A, Mascherpa D, Carazzone C, et al. (2013) Identification of organic acids in Cichorium intybus inhibiting virulence-related properties of oral pathogenic bacteria. Food Chem 138(2-3): 1706-1712.

69. Gallucci M, Fraire J, Ferreyra Maillard A, Paulina L Páez, Ivana M Aiassa Martínez, et al. (2017) Silver nanoparticles from leafy green extract of Belgian endive (Cichorium intybus L. var. sativus): Biosynthesis, characterization, and antibacterial activity. Mater Lett 197: 98-101.

70. Ayaz M, Ullah F, Sadiq A, Ullah F, Ovais M, et al. (2019) Synergistic interactions of phytochemicals with antimicrobial agents: Potential strategy to counteract drug resistance. Chem Biol Interac 308: 294-303.

71. Stefanović OD, Stanojević DD, Comić LR (2012) Synergistic antibacterial activity of Salvia officinalis and Cichorium intybus extracts and antibiotics. Acta Pol Pharm 69(3): 457-463.

72. Faiku F, Hazir A, Mehmeti I, Bajrami D, Haziri I (2016) Evaluation of antibacterial activity of different solvent extracts of Cichorium intybus (L.) growing wild in east part of kosovo. The J Anim Plant Sci 26(5): 1486-1491.

73. Karakaş F, Yildirim A, Türker A (2012) Biological screening of various medicinal plant extracts for antibacterial and antitumor activities. Turk J Biol 36: 641-652.

74. Petrovic J, Stanojkovic A, Comic L, Curcic S (2004) Antibacterial activity of Cichorium intybus. Fitoterapia 75(7-8): 737-739.

75. Koner A, Ghosh S, Roy P (2011) Isolation of antimicrobial compounds from chicory (Cichorium intybus L.) root. International Journal of Research in Pure and Applied Microbiology 1(2): 13-18.

76. Jeong D, Kim D-H, Chon J-W, Kim, Hyunsook, Kim Hong-Seok, et al. (2016) The Antimicrobial Activity of the Crude Extracts from Cichorium intybus L. (Chicory) against Bacillus cereus in Various Dairy Foods. J Milk Sci Biotechnol 34(4): 239-244.

77. Khalaf H, El-Saadani R, El-Desouky A, Abdeldaiem M, Elmehy M (2018) Antioxidant and antimicrobial activity of gamma-irradiated chicory (Cichorium intybus L.) leaves and roots. Journal of Food Measurement and Characterization 12(3): 1843-1851.

78. Liu H, Wang Q, Liu Y, Chen G, Cui J (2013) Antimicrobial and antioxidant activities of Cichorium intybus root extract using orthogonal matrix design. J Food Sci 78(2): M258-63.

79. Rahman H, Khan UA, Qasim M, Noor Muhammad,Muhammad Daud Khan, et al. (2016) Ethnomedicinal Cichorium intybus seed extracts: An impending preparation against multidrug resistant bacterial pathogens. Jundishapur J Microbiol 9(11): e35436.

80. Al Akeel R, Al-Sheikh Y, Mateen A, Syed R, Janardhan K, et al. (2014) Evaluation of antibacterial activity of crude protein extracts from seeds of six different medical plants against standard bacterial strains. Saudi J Biol Sci 21(2): 147-151.

81. Peerzada T, Gupta J (2018) Distribution of phytochemicals in stems and leaves of Cichorium intybus and Matricariachamomilla: assessment of their antioxidant and antimicrobial potential. BioTechnologia 99(2): 119-128.

82. Abdullah BH, Al-Saedi F, Salman AE (2019) Effects of Cichorium intybus methanolic extracts on some clinical bacterial isolates. Indian j public health res dev 10(2): 829

83. Ijaz A, Ahmad S, Gul H, Jabeen N, Gulfraz M (2017) Antioxidant and antimicrobial activities of root leaves and flowers of Cichorium intybus. IJP 4(1): 23-32.

84. Moghaddam NS, Eryılmaz M, Altanlar N, Yıldırım Ö (2019) Antimicrobial screening of some selected Turkish medicinal plants. Pak J Pharm Sci 32(3): 947-951.

85. Li G-Y, Gao H-Y, Huang J, Lu J, Gu J-K, et al. (2014) Hepatoprotective effect of Cichorium intybus L., a traditional Uighur medicine, against carbon tetrachloride-induced hepatic fibrosis in rats. World J Gastroenterol 20(16): 4753-4760.

86. Nallamilli BR, Phani Kumar CS, Veer Reddy K, Lakshmi Prasanna M, Maruthi V, et al. (2013) Hepatoprotective activity of Cichorium intybus (Linn.) root extract against carbon tetrachloride induced hepatotoxicity in albino Wistar rats. Drug Inven Today 5(4): 311-314.

87. Zafar R, Mujahid Ali S (1998) Anti-hepatotoxic effects of root and root callus extracts of Cichorium intybus L. J Ethnopharmacol 63(3): 227-231.

88. Ripoll C, Schmidt BM, Ilic N, Nebojsa Ilic, Alexander Poulev, et al. (2007) Anti-inflammatory effects of a sesquiterpene lactone extract from chicory (Cichorium intybus L.) roots. Nat Prod Commun 2(7): $1934578 \times 0700200$ 
89. Dalar A, Konczak I (2014) Cichorium intybus from Eastern Anatolia: Phenolic composition, antioxidant and enzyme inhibitory activities. Ind Crops Prod 60: 79-85.

90. Hosomi A, Nakanishi T, Fujita T, Tamai I (2012) Extra-renal elimination of uric acid via intestinal efflux transporter BCRP/ABCG2. PLoS ONE 7(2): e30456

91. Bian M, Lin Z, Wang Y, Zhang B, Li G, et al. (2018) Bioinformatic and metabolomic analysis reveal intervention effects of chicory in a quail model of hyperuricemia. Evidence-Based Complementary and Alternative Medicine 2018: 1-13.

92. Mohammad S, Khizar A, Faiza N, Ahmad Mobasher, Nawazish-i-Husain Syed, et al. (2014) Anticancer activity of n-hexane extract of Cichorium intybus on lymphoblastic leukemia cells (Jurkat cells). Afr J Plant Sci 8(6): 315-319.

93. Kim HM, Kim HW, Lyu YS, J H Won, D K Kim, et al. (1999) Inhibitory effect of mast cell-mediated immediate-type allergic reactions by Cichorium intybus. Pharmacol Res 40(1): 61-65.

94. Rifat-uz-Zaman, Akhtar MS, Khan MS (2006) Anti-ulcerogenic screening of Cichorium intybus L. leaf in indomethacin treated rats. Int J Pharmacol 2(2): 166-170.

95. Gürbüz İ, Üstün O, Yeşilada E, Sezik E, Akyürek N (2002) In vivo gastroprotective effects of five Turkish folk remedies against ethanolinduced lesions. J Ethnopharmacol 83(3): 241-244.

96. Woolsey ID, Valente AH, Williams AR, Thamsborg SM, Simonsen HT, et al. (2019) Anti-protozoal activity of extracts from chicory (Cichorium intybus) against Cryptosporidium parvum in cell culture. Sci Rep 9(1): 20414.

97. Wang Y, Lin Z, Zhang B, Wang X, Chu M (2019) Chicory (Cichorium intybus L.) inhibits renal reabsorption by regulating expression of urate transporters in fructose-induced hyperuricemia. J Tradit Chin Med Sci 6(1): 84-94.

98. Kianbakht S (2012) Medicinal plants used in treatment of rhematologic diseases: A systematic review. J Med Plants 11(41): 30-56.

99. Mansouri A, Esmaeili F, Nejatpour A, Houshmand F, Shabani L, et al (2016)Differentiation of P19 embryonal carcinoma stem cells into insulin-producing cells promoted by pancreas-conditioned medium. Tissue Eng Regen Med 10(7): 600-612.

100. Mehrfarjam Z, Esmaeili F, Shabani L, Ebrahimie E (2016) Induction of pancreatic $\beta$ cell gene expression in mesenchymal stem cells: B cel induction of mesenchymal stem cells. Cell Biol Int 40(5): 486-500.

101. Ebrahiminia M, Esmaeili F, Shabani L (2020) In vitro differentiation induction of embryonal carcinoma stem cells into insulin-producing cells by Cichorium intybus L. leaf extract. J Ethnopharmacol 246: 112214.

102. Ning C, Wang X, Gao S, Jingjing Mu, Yuehua Wang et al. (2017) Chicory inulin ameliorates type 2 diabetes mellitus and suppresses JNK and MAPK pathways in vivo and in vitro. MolNutr Food Res 61(8).

103. Olsen NJ, Branch VK, Jonnala G, Seskar M, Cooper M (2010) Phase 1, placebo-controlled, dose escalation trial of chicory root extract in patients with osteoarthritis of the hip or knee. BMC Musculoskelet Disord 11(1): 156

104. Minaiyan M, Ghannadi A-R, Mahzouni P, Abed A-R (2012) Preventive effect of Cichorium intybus L. two extracts on cerulein-induced acute pancreatitis in mice. Int J Prev Med 3(5): 351-357.
105. Hazra B, Sarkar R, Bhattacharyya S, Roy P (2002) Tumour inhibitory activity of chicory root extract against Ehrlich ascites carcinoma in mice. Fitoterapia 73(7-8): 730-733.

106. Bischoff TA, Kelley CJ, Karchesy Y, Laurantos M, Nguyen-Dinh P, et al. (2004) Antimalarial activity of lactucin and lactucopicrin: sesquiterpene lactones isolated from Cichorium intybus L. J Ethnopharmacol 95(2-3): 455-457.

107. Azay-Milhau J, Ferrare K, Leroy J, et al. (2013) Antihyperglycemic effect of a natural chicoric acid extract of chicory (Cichorium intybus L.): a comparative in vitro study with the effects of caffeic and ferulic acids. J Ethnopharmacol 150(2): 755-760.

108. Lee KT, Kim JI, Park HJ, Yoo KO, Han YN, et al. (2000) Differentiationinducing effect of magnolialide, a 1 beta-hydroxyeudesmanolide isolated from Cichorium intybus, on human leukemia cells. Biol Pharm Bull 23(8): 1005-1007.

109. Amirghofran Z, Azadbakht M, Karimi MH (2000) Evaluation of the immunomodulatory effects of five herbal plants. J Ethnopharmacol 72(1-2): 167-172

110. Hasannejad F, Ansar M, Rostampour M, Mahdavi Fikijivar E KhakpourTaleghani B (2019) Improvement of pyridoxine-induced peripheral neuropathy by Cichorium intybus hydroalcoholic extract through GABAergic system. The Journal of Physiological Sciences 69(3): 465-476.

111. Sultana S, Perwaiz S, Iqbal M, Athar M (1995) Crude extracts of hepatoprotective plants, Solanum nigrum and Cichorium intybus inhibit free radical-mediated DNA damage. J Ethnopharmacol 45(3): 189-192.

112. Nayeemunnisa, Rani MK (2003) Cardioprotective effects of Cichorium intybus in ageing myocardium of albino rats. Curr Sci 84(7): 941-943.

113. Zhang HL, Dai LH, Wu YH, Xiao-Ping Yu, Yong-Yong Zhang, et al (2014) Evaluation of hepatocyteprotective and anti-hepatitis B virus properties of Cichoric acid from Cichorium intybus leaves in cell culture. Biol Pharm Bull 37(7): 1214-1220.

114. Bayazid AB, Park SH, Kim JG, Lim BO (2020) Green chicory leaf extract exerts anti-inflammatory effects through suppressing LPS-induced MAPK/NF- $\mathrm{KB}$ activation and hepatoprotective activity in vitro. Food Agric Immunol 31(1): 513-532.

115. Hozayen W, El-Desouky M, Soliman H, Ahmed R, Khaliefa A (2016) Antiosteoporotic effect of Petroselinum crispum, Ocimumbasilicum and Cichorium intybus L. in glucocorticoid-induced osteoporosis in rats. BMC Complement Altern Med 16(1).

116. Conforti F, Ioele G, Statti GA, Marrelli M, Ragno G, et al. (2008) Antiproliferative activity against human tumor cell lines and toxicity test on Mediterranean dietary plants. Food Chem Toxicol 46(10): 3325-3332.

117. Heibatollah S, Reza N, Izadpanah G, Sohailla S (2007) Hepatoprotective effect of Cichorium intybus on CCl4-induced liver damage in rats. Afr. J. Biochem. Res 2(6): 141-144.

118. Gilani A, Janbaz K (1994) Evaluation of the liver protective potential of Cichorium intybus seed extract on Acetaminophen and CCl4-induced damage. Phytomedicine 1(3): 193-197.

119. Pourfarjam Y, Rezagholizadeh L, Nowrouzi A, Alipasha Meysamie, Sarah Ghaseminejad, et al. (2017) Effect of Cichorium intybus L. seed extract on renal parameters in experimentally induced early and late diabetes type 2 in rats. Ren Fail 39(1): 211-221. 
ISSN: 2574-1241

DOI: 10.26717/BJSTR.2021.35.005662

Gohar Taj. Biomed J Sci \& Tech Res

\section{(C) P) This work is licensed under Creative}

Submission Link: https://biomedres.us/submit-manuscript.php

$\begin{array}{ll}\text { BIOMEDICAL } & \text { Assets of Publishing with us } \\ \text { RESEARCHES } & \text { Global archiving of articles } \\ & \text { - Immediate, unrestricted online access } \\ & \text { - Rigorous Peer Review Process } \\ & \end{array}$

